РЕЦЕНЗІї

DOI https://doi.org/10.32844/2618-1258.2020.1.53

КЕЛЬМАН М.С.

\title{
РЕЦЕНЗІЯ НА МОНОГРАФІЮ ЛЮДМИЛИ МИХАЙЛІВНИ АНДРУСІВ «ТЕХНІКО-ЮРИДИЧНІ ТА МЕТОДОЛОГІЧНІ ЗАСАДИ ОПРИЛЮДНЕННЯ НОРМАТИВНО-ПРАВОВИХ АКТІВ»
}

Потреба в грунтовних наукових дослідженнях у сфері оприлюднення нормативно-правових актів постала давно з огляду не лише на їх відсутність, а й на забезпечення доступу до великої кількості нормативно-правових актів, які приймаються, ухвалюються та видаються органами держави й органами місцевого самоврядування. Монографія Л.М. Андрусів «Техніко-юридичні та методологічні засади оприлюднення нормативно-правових актів» $€$ першим вагомим науковим дослідженням техніки оприлюднення нормативно-правових актів.

У першому розділі, окрім методологічних засад, розкрито значення оприлюднення нормативно-правових актів у контексті парадигми якості нормативно-правових актів, право на інформацію про нові нормативно-правові акти, забезпечення функціонування презумпції «незнання закону не звільняє від відповідальності», а також реалізацію принципу правової визначеності.

Доктринальні положення оприлюднення нормативно-правових актів розглянуто у другому розділі монографії. Зокрема, сформовано теоретичні положення принципів оприлюднення нормативно-правових актів, які є вихідними засадами для діяльності суб'єктів правотворчості щодо доведення змісту нормативно-правового акта до відома суб’єктів права.

Стан правової регламентації оприлюднення нормативно-правових актів в Україні та специфіку практики оприлюднення нормативно-правових актів досліджено у третьому розділі монографії. Обгрунтовано потребу в чіткій нормативно-правовій регламентації оприлюднення нормативно-правових актів в Україні, надано пропозиції щодо вдосконалення існуючого стану.

Практичне значення мають сформовані в четвертому розділі техніко-юридичні правила щодо оприлюднення нормативно-правових актів, а також вимоги до офіційних електронних вебсайтів органів держави та органів місцевого самоврядування, які використовуються для оприлюднення нормативно-правових актів щодо безпеки й захисту офіційного вебсайту від несанкціонованого редагування, зміни та знищення текстів нормативно-правових актів, забезпечення безперервної роботи й доступу до оприлюднених на ньому нормативно-правових актів.

У п'ятому розділі зосереджено увагу на досвіді зарубіжних країн з оприлюднення нормативно-правових актів. Для цього автор використовує нормативно-правові акти зарубіжних країн, що регулюють порядок оприлюднення.

Загалом робота свідчить про грунтовне опрацювання вітчизняного й зарубіжного теоретичного та нормативно-правового матеріалу, насамперед матеріалу щодо країн Європи та країн, які є близькими сусідами держави (Польської Республіки та Республіки Білорусь). Проблема, обрана автором для дослідження, справді $є$ актуальною, розкрита нею кваліфіковано із залученням значної кількості джерел. Монографія Л.М. Андрусів $є$ завершеним науковим дослідженням, має наукову та практичну цінність з огляду на можливість упровадження результатів у сферу оприлюднення нормативно-правових актів.

${ }^{1}$ Андрусів Л.М. Техніко-юридичні та методологічні засади оприлюднення нормативно-правових актів : монографія. Київ : Кушнір Г.М., 2020. 444 с

(C) КЕЛЬМАН М.С. - доктор юридичних наук, професор, професор кафедри теорії, історії та філософії права (Інститут права, психології та інноваційної освіти Національного університету «Львівська політехніка») 